\title{
XIX. Yüzyıla Ait Bir Şiir Mecmuası
}

\author{
XIX. Century Poetry Magazines
}

Nuray ÇALIŞKAN

\section{Özet}

Klasik Türk Edebiyatı, tarihî ve edebî yönden son derece zengin ve önemli eserlere sahiptir. Bu eserlerden biri olan mecmuaların pek çok türü olmakla birlikte bunlardan biri şairlerin şiirlerinin yer aldığg mecmualardır. Öyle ki bu kaynaklarda çoğu şairin kendi divanlarında veya diğer eserlerinde yer almayan şiirlerine rastlamak mümkündür. Söz konusu eserlerin günümüze aktarılması ve tanıtılması; yeni yorumlara, bilgilere ve gün yüzüne çıkmamıs nice şiirlerin ortaya çıkmasına vesile olacaktır. Mecmualar, belli bir edebî zevki yansıttığı için şiirler hakkında yorumlara da imkân sağlayacaktır. Bu sebeple mecmualar, Klasik Türk Edebiyatı araştırmacılarının başvuracağı önemli kaynaklar arasında yer almaktadir.

Çalışmanın amacı, Millet Kütüphanesi, AE Manzum 558 numarada kayıtlı olan bir şiir mecmuasını tanıtmaktır. Çalışmanın konusu olan ve müstensihi belli olmayan bu şiir mecmuası, daha önce çalışılmadığ 1 için makale konusu olarak seçilmiştir. Mecmuadaki gazeller, XVIII ve XIX. yüzyılın ünlü simalarına ait olup tür olarak hiciv ve hezliyatları içermektedir. Çalışmada Türk edebiyatında hiciv konusu kısaca açıklanarak mecmuada yer alan şairlerin şiir ve hiciv örnekleri hakkında bilgi verilmiştir. Ayrıca şiirlerin dili, anlatımı ve eserin şekil özellikleri üzerinde durularak mecmuanın tanıtımı yapılmıştır.

Anahtar kelimeler: Klasik Türk Edebiyatı, XIX. Yüzyıl, Hiciv, Şiir Mecmuası

\begin{abstract}
Classical Turkish Literature has extremely rich and important works from historical and literal perspective. The magazine that is one of these works, is the sources in which poetry takes place. In these sources, it is possible to find poems that most poets do not have in their divans or other works. The introduction of these works in question and the tranference of them to these days are to conduce new interpretations and informations and also appearance of several great poens that known before. Since the magazine reflects a certain literary taste, it is also tol et the interpretations about poems. For this reason, the magazin's amang the first sources that Classical Literature researchs apply.
\end{abstract}

The aim of this article is to introduce poetry magazine that is registered in Millet Library by the none of "Hicivler Mecmuasi".This poetry magazine which is the sugeet of the article and wich has not definite wirter has been chosen as the subject of the paperc since it has not been studied before poetry in the magazine belongs to famous writers of XIX. Century and indudes satir and jokes as a kinds. In this article information about the magazine the parts taking place in this work and examples of poems and satirs of these work. Further more, the magazine has been introduced by putting emphasis on the language narration of peoms and the styliestic feature and contant of the work.

Key Words:Classical Turkish Literature, XIX. Centruy, Satire, Poems Magazines

Yüksek Lisans Öğrencisi, Uludağ Üniversitesi, nuray.clsknn@gmail.com 


\section{Giriş}

Sözlüklerde“dağınık şeyleri bir araya getirmek, toplamak”( Parlatır: 2006; Şemseddin Sami:2007; Develioğlu: 2010)anlamlarına gelen mecmû'a kelimesi Arapça kökenli bir sözcük olup cem mastarından türetilmiştir. Edebî terim olarak ise mecmûá; "tertip ve tanzim edilmiş, seçilmiş yazılardan meydana getirilmiş kitap" anlamına gelmektedir.

Yazılı metinler üzerinde yapılan çalı̧̧maların önemli bir adımı metin çevirisi ve incelemesidir. $\mathrm{Bu}$ sebeple yeni eserleri gün yüzüne çıkarmak; geçmiş ve gelecek arasında bir bağ ve birikim olanağ1 sağlayan metinleri günümüze aktarmak ve tanıtmak dikkatle üzerinde durulması gereken bir konudur. $\mathrm{Bu}$ anlamda günümüz araştırmacılarının da ilgisine mazhar olan ve onlara önemli malzemeler sağlayan metinlerin başında mecmualar gelmektedir. Bugün sadece ülkemizin değişik yerlerindeki kütüphanelerde yüzlerce mecmua vardır ve bunların bir kısmı tespit edilmiş, üzerinde çalışmalar yapılmıştır.

Mecmualar, genelde birden çok müellife veya şaire ait çeşitli nesir veya nazım örneklerinin yer aldığı eserlerdir. Bunlar aşk, din, tasavvuf, sosyal hayat, musiki, hiciv, hadîs, âyet gibi konuların yanı sıra başka alanlarda da yazılmışlardır.

Mecmualar, farklı ve birden çok yazar ve şaire ait şiirleri bir araya toplaması bakımından önemlidir. Birçok kişiye ait şiir ve nesir örneği görülebileceği gibi farklı tarz ve üsluplara da rastlanılmasına imkân sağlamaktadır. Bu eserler dönemin şiir zevkini bildirmesi bakımından da önemlidir. Bununla beraber şairlerin divanlarında ve eserlerinde -eserlerin birçok nüshası görülmesine rağmen- yer almayan birçok nazım ve nesir örneğine mecmualarda rastlanmaktadır. Bu da başka bir şaire/yazara ait yeni nazım/nesir örneklerine ulaşılmasında, yeni bilgiler elde edilmesinde imkân sağlamaktadır. $\mathrm{Bu}$ açıdan mecmuaların incelenmesi hem yeni bilgilerin, şiirlerin, yazıların hem de yeni şair ve münşilerin bilinmesinde, birbirleriyle münasebeti olanların tespitinde ve şairlerin veya adı geçen diğer kişilerin biyografileri hakkında yeni bilgilerin elde edilmesinde Türk edebiyatına önemli katkı ve birikimler sağlamaktadır. Kısaca mecmualar önemli olup Türk edebiyatının, Türk edebiyatı tarihinin yardımcı kaynaklarındandır (Kut: 1986:170; Aydemir:2007:123-126; Köksal:2012:417-420; Tunç: 2015:316).

Mecmualarda da pek çok tür gibi tasnif yöntemine gidilmiştir. Bu konuda çeşitli çalışmalar yapılmıştır. Çalı̧̧mada Agâh Sırrı Levend'in tasnifine yer verildi. Levend, mecmuaları şu şekilde tasnif etmiştir:

a) Nazireler mecmualar1,

b) Meraklılarca toplanmış, birer antoloji niteliğinde seçme şiirler mecmuaları,

c) Türlü konulardaki risalelerin bir araya getirilmesiyle meydana gelen mecmualar,

ç) Aynı konudaki eserlerin bir araya getirilmesiyle meydana gelen mecmualar,

d) Tanınmış kişilerce hazırlanmış, birçok yararlı bilgileri, fikraları ve özel mektupları kapsayan mecmualar. (Levend:1984:166-167).

\section{Hiciv ve Hicivler Mecmû́ası Hakkında}

Hiciv kelimesi dilimize Arapçadan geçmiş olup kökeni hecv ve hicâ kelimelerine dayanmaktadır. Bir kelimeyi harflerini sayarak ve heceleyerek okumak, bir kişinin ya da toplumun ayıp ve kusurlarını sayıp dökmek, yermek anlamına gelmektedir (Mermer-Koç Keskin:2005:40) Türk edebiyatında hicvin geçmişi oldukça eskidir. Klasik Türk Edebiyatıyla birlikte gelişen ve edebiyatımızda yer eden 
bir alandır. Bu alanda yapılan araştırmaların sınırlı olması bu türe yeni yeni önem verildiğini göstermektedir. İslam kültürüyle yoğrulmuş Osmanlı toplumunda kişilerin fiziksel özellikleriyle dalga geçildiği ve onur kırdığı gerekçesiyle pek hoş karşılanmamıştır. Hiciv yazdığı için idam edilen veya sürgüne gönderilen şairler (Nefî̀, Haşmet, Figânî... gibi) bu durumu kanıtlar nitelikteki örneklerden yalnızca birazıdır.

Kur'ân-1 Kerîm'de de hicve sıcak bakılmamış; kendi çıkarı için övdüğünü yeren, yerdiğini öven ayık olmayanı metheden veya haksız yere kötüleyen, bu doğrultuda yalan ve iftiradan sakınmayan, sözü fiiline uymayan, 1rz ve namusa saldıran şairler yerilmiştir (Durmuş:1998:449).

"Birbirine söven iki kişinin söyledikleri sözün günahı -haksızlığa uğrayan sınırı aşmadıkça- sövmeyi ilk başlatanadır” Hz. Muhammed. (Kocaer: tarihsiz: 567)

Ayet ve hadislerde de söylendiği üzere hicivde kullanılan kelimelere olumsuz bakıldığı ortadadır. Kaldıki mecmuada yukarıda örneklenen ifadelere uygun olarak kullanılan birçok gayrı ahlaki söz ve dinsizlik suçlaması mevcuttur. (Bre dinsiz bre kahpe bre hınzır oglan...) Bu yasaklara rağmen şairler bu türde eser vermekten kendilerini alamamıs, hiciv yazmaya devam etmişlerdir. Bu duruma, mecmuada yer alan Haşmet(ö. 1181-82/1768)'in hicvettiği kişiye onu hicvetmesindeki sebebi yani hicvi terk edemeyişini söylediği şu dizeler de örnek teşkil eder:

Ben seni hicve tenezzül mü iderdim böyle

Nişleyim terk idemem kaide-i eşarı

\section{a) Eserin Adr, Müellifi ve Te'lif Tarihi}

Çalışmanın konusu olan Hicivler Mecmuass, İstanbul Millet Kütüphanesi, Ali Emiri Koleksiyonu'nda bulunmuştur. AE Manzum 558 numarada kayıtlıdır. Eser birebir görülmediği için veritabanından elde edilen bilgilerden yararlanılmıştır. Burada yer alan bilgilerde, eserin başında ve sonunda müellifi veya müntensihi hakkında bir bilgi yoktur. Çalışmalar ve mecmua üzerinde yapılan incelemeler neticesinde herhangi bir bilgiye rastlanılmamı̧̧ır. Eser, kütüphane kaydında "Hicivler Mecmuası” adı yer almışır. Te'lif tarihi de bilinmemektedir. Fakat eserde yer alan şairlerin yaşadıkları yüzyıllardan yola çıkılarak mecmuanın XVIII.Yüzyıl sonrasında yazılmış olabileceği tahmin edilebilir.

\section{b) Nüsha Tavsifi ve Mecmuanın Şekil Özellikleri}

Varak sayısı 43; cilt: tam meşin, tezhipli, zencirekli; yazı çeşidi Arap-talik, satır sayısı 17'dir (çift sütun). Söz başları kırmızı olup eserin dili Türkçedir. Eserin yazılış tarihi hakkında bir bilgi yer almamaktadır.

Baş: $\quad$ Kise-dar-1 haremeyn ey kekezün biarı

Be gidi avretini s......... mürdarı

Son: Müciz olan egerçi merd-i dana Abdiya amma

Zamanın arzu-yı yal u balı artar eksilmez

Mecmua; birçok kaside, gazel, kıt'a nazım şekli, müfred beyit ve tarih kıtası içermektedir. Bu şiirlerin dikkat çeken yönü hemen hepsinin küfür ve ağır ithamlarla dolu olmasıdır. Eser, 43 varak olup 14 sayfası hiçbir şey yazılmamış boş sayfalardır. Manzumelerin çoğu talik; fakat yer yer bozuk rika yazı ile kaydedilmiştir. Şiirlerin bir kısmı derkenarlara yazılmıştır ve cetvel yoktur. Mecmuada Arap rakamlarıla sayfa numaralandırması yapılmamıştır fakat kurşun kalemle sonradan eklenen Türkçe 
rakamlar vardır. Şiirlerin diziliminde de belli bir sıra gözetilmediği görülmektedir. Aynı şaire ait şiirler başka varaklarda da yer almaktadır. Aynı şaire ait iki şiir arka arkaya verilmişse bile bunun için bir not düşülmemiştir. Başlıklarda nazım biçimi, hicvin yazıldığı kişinin adı, mesleği hatta şairin ona verdiği kötü sıfatlar bile anılmıştır: "Ümmü'l-fesâd ebû'l-fitne Hamdullah-1 bî-hayânun..." gibi. Bunun yanında bazı şairlerin mahlas beyitlerinde adları da kırmızı renkle yazılmıştır.

Eserde yine kelimelerin bazıları yer yer siyah ve kırmızı renkle harekelendirilmiştir. Bununla beraber birkaç beyit de kırmızı renkle yazılmıştır ${ }^{1}$. Burada müellifin imlası ve hareke özellikleri dikkate alınarak örnek şiirler transkribe edilmiştir. Birbirine küfürlü şiirler yazan şairlere veya bir başka tanınan şaire küfreden birçok şaire ve şiirine bu mecmuada rastlanmaktadır. Eserde şiirler, genel itibariyle düzenli, nazım şekilleri doğru ve uygun şekilde yazılmıştır. Şiirlerin bir araya getirilmesinde mecmuanın başından sonuna kadar herhangi bir sıra gözetilmemiştir. Alfabetik veya nazım türleri şeklinde bir sıralama mevcut değildir.Aynı şaire ait şiirler de mecmua içerisinde art arda değil, farklı varaklarda bulunmaktadır.Eserde adı geçen şairler: Haşmet (d. ?-?-ö.1768/1181-82), Hevayi (d. 1290/1873-ö. 1334/1916), Fatin (d.1814-ö.1866), Arif Hikmet (d. 1201/1786-ö. 1275/1859), Avni(d. 1243/1827-ö. 1289/1872), -Nazmi (d.?-?-ö. 1066/1655), İrfan Bey (d. ?-?-ö. 19. yy.-?), Esad Efendi( d. ?-?-ö. 1166/1753), Cevri (d.1005/1595(?)-ö.1065/1654), Resima (d. ?-?-ö. 1218/180304), Bahayi(d. ?-?-ö. 1071/1660), Faz1l Efendi(d. 1889-ö.1923), Pertev (d. ?-?-ö. 1276/1859), Fenni (d.?-?-ö. 1077/1666), Nabi(d. 1052/1642- ö. 1124/1712), Osmanzade Taib(d. 1070/1659-1660-ö. 1136/1724), Kani (d. 1124/17120-ö. 1206/1791), Abdi (d. ?-?-ö. 1302/1884), Hakkı Bey(d. 1238/1823-ö. 1312/1895), Rauf Bey (d. 1296/1879-ö.?-?), Süleyman Bey(d. ?-?-ö. 1099/1688), Naili (d. 24-1239/1823-ö. 1293/1876-77), Niyazi Katib(d. 1259/1844-ö. 1318/1900), Ziya Paşa(d. 1245/1829-ö. 1297/1880).

Mecmuada yer alan şairler, şiirleri; şiirlerin nazım biçimleri ve eserde şairlerin yer aldığı sıraya göre aşağıdaki tabloda bend/beyit sayılarıly verilmiştir:

\begin{tabular}{|l|l|l|}
\hline Şair & Nazım Biçimi & Bend/ Beyit Sayıs1 \\
\hline Haşmet & Kaside & 80 beyit \\
\hline Mahlassız & Kaside & 15 beyit \\
\hline Avni & Gazel & 5 beyit \\
\hline Esad Efendi & Gazel & 10 beyit \\
\hline Cevri & Gazel & 20 beyit \\
\hline Resima & Kaside & 30 beyit \\
\hline Nazmi & Kit'a 13 adet & 2 beyit \\
\hline Arif Hikmet & Kit'a & 2 beyit \\
\hline La Edri & Gazel & 22 beyit \\
\hline Bahayi & Müseddes & 5 bend \\
\hline Bahayi & Muhammes & 5 bend \\
\hline Mehmed Fazil & Tahmis & 10 beyit \\
\hline Nabi & Müfred 3 adet & 1 beyit \\
\hline Bahayi & Müfred 2 adet & 1 beyit \\
\hline Pertev & Gazel & 8 beyit \\
\hline Fenni & Kaside & 62 beyit \\
\hline Osmanzade Taib & Gazel & 7 beyit \\
\hline Kani & Gazel & 5 beyit \\
\hline Hasib Kazi & Gazel & 7 beyit \\
\hline Şebinkarahisarlı Abdi & Gazel & 7 beyit \\
\hline
\end{tabular}

${ }^{1}$ [4a], [5a], [6a], [33a]. 


\begin{tabular}{|l|l|l|}
\hline Namık Bey & Kit'a & 2 beyit \\
\hline Hakkı Beg & Kaside & 36 beyit \\
\hline Fatin & Müfred & 26 beyit \\
\hline Ziya Paşa & Kaside & 58 beyit \\
\hline Süleyman Beg & Kaside & 52 beyit \\
\hline Fatin & Kit'a 6 tane & 2 beyit \\
\hline Naili & Kit'a 2 tane & 2 beyit \\
\hline Fatin & Gazel & 15 beyit \\
\hline Riza & Kit'a & 2 beyit \\
\hline Fazli & Kit'a & 2 beyit \\
\hline Nihad Beg & Kit'a & 2 beyit \\
\hline Ziya Beg & Kit'a & 2 beyit \\
\hline Rauf Beg & Kit'a 2 adet & 2 beyit \\
\hline Azmi Beg & Kit'a & 2 beyit \\
\hline Tahir Efendi & Kit'a 22 tane & 2 beyit \\
\hline İsmet Beg & Kit'a & 2 beyit \\
\hline Raşid Efendi & Kit'a & 2 beyit \\
\hline Molla & Muhammes & 5 bend \\
\hline Niyazi & Gazel & 10 beyit \\
\hline Hevayi & Gazel & 10 beyit \\
\hline Hevayi & Gazel & 5 beyit \\
\hline Hevayi & Gazel & 5 beyit \\
\hline Hevayi & Gazel & 5 beyit \\
\hline Hevayi & Gazel & 7 beyit \\
\hline Fazıl paşa & Kaside & 66 beyit \\
\hline Fazil Paşa & Gazel & 9 beyit \\
\hline Fazıl Pşa & Kit'a & 2 beyit \\
\hline Fatin & Kaside & 29 beyit \\
\hline Abdi & Gazel & 7 beyit \\
\hline Gelibolulu Ali & Gazel & 11 beyit \\
\hline Mahlassiz & Kit'a & 66 adet \\
\hline Mahlassız & Müfred & 25 adet \\
\hline & & \\
\hline & & \\
\hline
\end{tabular}

Makalede ayrıca şairi belli olmayan şiirler 'Mahlassız' ifadesiyle belirtilerek verilmiştir. Mecmuada yer alan şiirlerin nazım biçimleri ve bu nazım biçimlerinin şiir sayıları şu şekildedir:

\begin{tabular}{|l|l|}
\hline Nazım Biçimi & Şiirlerin Sayı \\
\hline Kaside & 6 \\
\hline Gazel & 19 \\
\hline Müseddes & 1 \\
\hline Muhammes & 2 \\
\hline Kit'a & 150 \\
\hline Müfred & 30 \\
\hline
\end{tabular}


Birçok nazım şekli bulunan mecmuada daha çok kıt'alar yer almaktadır. Kıt'aları sırasıyla müfred beyitler, gazel, kaside, muhammes ve müseddes nazım şekilleri izlemiştir. Mecmuada bu şiirler dağınık olarak verilmiş olup nazım şekline veya şairlerin isim sırasına göre düzenlenmemiştir.

\section{c) Mecmuanın İ̧eriği ve Dil Özelliğine Dair}

Mecmuanın dili Türkçe olmakla birlikte mecmuada bazı şiirlerde Farsça ve Arapça kelimeler de yer almakta ve mecmuadaki bazı beyitlerin bir kısmında vezin problemlerin olduğu görülmektedir. Bazı yerlerde peze.nk kelimesi 'p' bazı yerlerde ile 'b' ile yazılmıştır. Diğer bir farklılık da 'nun' ve 'damak ๆ’sinde görümektedir. Bazı yerlerde bu harflerin birbirlerinin yerine kullanıldığ1 -aynı metin içinde bile-görülmektedir. Mecmuada toplanan şiirler, az tanınan veya çok bilinen şairlere ait nazım örnekleridir. Şiirlerin içeriğine baktığımızda kayıtlı şiirlerden birkaçı hariç neredeyse hepsi hiciv örneği olup "gazel, kaside, kıt’a, mısra, manzum, müfret beyit, tarih kıtası "nazım biçimlerine aittir.

Eserde karşılaşılan ve dikkat çeken bir husus da şairlerin karşılıklı hicivlerine yer verilmesidir. Naili ile Fatin Efendi'nin birbirlerine yazdığı ve Fazıl Efendi'nin Ziya Paşa’ya yazdığı hicviyyelerden örnek teşkil etmesi açısından aşağıda verilmiştir:

\begin{tabular}{|c|c|}
\hline Nā'ilî & Fatịn Efendi \\
\hline 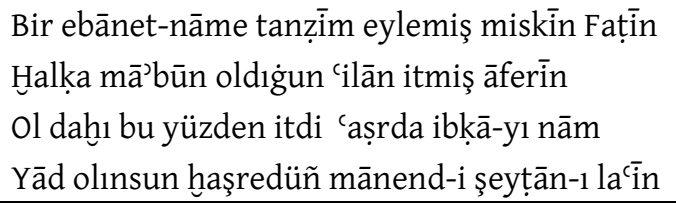 & 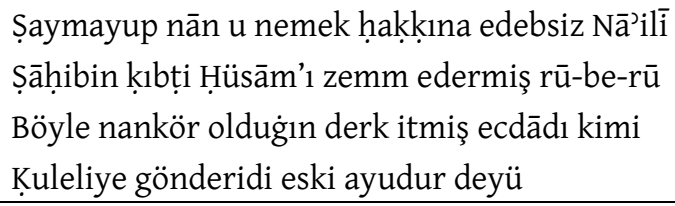 \\
\hline Fāzil Efendi & Fāzil Efendi \\
\hline $\begin{array}{l}\text { Māhtābı bozulup yanmadı kandil-i fesād } \\
\text { Virmege hażır iken şu'lesini fitne Ziyā } \\
\text { Ḳaldı zulmette ḩıraş ü havf oldu țārı } \\
\text { Pāris'i dārü’l-emān eyledi cān attı aña }\end{array}$ & $\begin{array}{l}\text { Ehl-i īmān eylemez tebiyet-i efrenc bed } \\
\text { Müslümān olsa Żiyā eyler mi idi irtikāb } \\
\text { Bir şakāāvet etti ki emsāli sebḳat etmedi } \\
\text { Varsın olsun '̇ंsevīler mezhebiyle kām-yāb }\end{array}$ \\
\hline
\end{tabular}

Mecmuada kıt’a, mısra, müfret beyte çokça tesadüf edilmesi bu dönemin özelliklerini yansıtmaktadır. Mecmuada yer alan şiirlerin "matla" ve "makta" beyitlerinden örnekler aşağıdaki tabloda verilmiştir. Beyitlerde yer alan özellikle küfürlü ve müstehcen ifadeler “...” (noktalı) şekilde yazılmıştır:

\begin{tabular}{|c|c|c|}
\hline Mahlas & Matla Beyti/Bendi & Makta Beyti/Bendi \\
\hline Haşmet & $\begin{array}{l}\text { Kî̀se-dār-1 haremeyn ey kekezüñ bi'ār1 } \\
\text { Be gidi 'avretini s.......... mürdār1 }\end{array}$ & $\begin{array}{l}\text { Ey cefūd puşt āb u ecdādına lacnet olsun } \\
\text { Ḥānedānına köpekler işesün şar şarı }\end{array}$ \\
\hline Mahlassız & $\begin{array}{l}\text { Yine bir müfsid itdi hậ̄ı̣rım ġāyet perīșānī Göñül } \\
\text { mülki harāb oldu yapılmaz ġayrı virānı }\end{array}$ & $\begin{array}{l}\text { Bunuñla gerçi ıșlāḥ olmayup eylerse müfsidlik } \\
\text { Anuñ ḩaḳkında nev-īicād idem bir pāre divanı }\end{array}$ \\
\hline Fatīn Efendi & 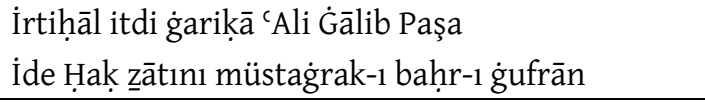 & $\begin{array}{l}\text { Cevher-i ferd idi devletde vücūd-i pāki } \\
\text { Kaacr-1 deryāda felek itdi anuñçün pinḥān }\end{array}$ \\
\hline 'Ārif Hikmet & $\begin{array}{l}\text { Hikmetā Ḥakkk'a bakıın kim ‘Ali Ġālib Paşa } \\
\text { Nāgehānī oğulup imdi belāsın buldı }\end{array}$ & $\begin{array}{l}\text { Vālidi ölmüş idi kim şude-i hāāk sipāh } \\
\text { Bu sefer kendi lebīde bahrde meftūūd oldu }\end{array}$ \\
\hline
\end{tabular}




\begin{tabular}{|c|c|c|}
\hline 'Avnī & $\begin{array}{l}\text { Te’ehhül ḳașduñ itdüm ey dirīiāā telh-i kām } \\
\text { oldum } \\
\text { Taḳıldı țoz țopra[k] boynuma rüsvā-yı 'ām } \\
\text { oldum }\end{array}$ & $\begin{array}{l}\text { Cenābetden kaçup ġamlar çekerdüm ihtilām } \\
\text { olsam } \\
\text { Cünübler zümresine 'Avnīyā şimdi imām oldum }\end{array}$ \\
\hline Es'ad Efendi & $\begin{array}{l}\text { Kad-riyā işte bu birḳaç manzūūm } \\
\text { Fārisīiden saña olsun ma'lūm }\end{array}$ & $\begin{array}{l}\text { Oḳu ezberle şu ebyāt-1 cayān } \\
\text { Fārisī söylemiş aḳdınla hemān }\end{array}$ \\
\hline Resīmā & $\begin{array}{l}\text { Dilberā cașrımızuñ mihr [ü] vefāsın s...... } \\
\text { 'Āşık-1 teb-zedenüñ żevḳ u șafāsın s..... }\end{array}$ & $\begin{array}{l}\text { Bu ru-ber șaçma bulunsun n'olur orțada kim } \\
\text { Şebhāā dahil eyleyenüñ ben de añasin s..... }\end{array}$ \\
\hline Lā Edrī & $\begin{array}{l}\text { Çatsa ġam felegi fenā bulsa n'ola kişte-i ten } \\
\text { Salunup pāyına geçmiş bir iki ip? sürüyen }\end{array}$ & $\begin{array}{l}\text { Ug̉rayup firtınaya bir gün eya hayz u denî } \\
\text { Alavānda ide kötün ḳayığı bād- } 1 \text { miḥen. }\end{array}$ \\
\hline Bahāyī & $\begin{array}{l}\text { Şimdi yüz miḥnet ile gam bizi öldürse mahal } \\
\text { Geh s...ş cilmini tahṣilde olduḳ echel }\end{array}$ & $\begin{array}{l}\text { Mīd hedd olmayacaḳ irmez imiş devlete el } \\
\text { Halḳa g.t virmegi beyhūde șanurduḳ evvel }\end{array}$ \\
\hline Hevāyī & $\begin{array}{l}\text { Gezmezdi șırıḳlarda ciger çevren olaydım } \\
\text { Bitmezdi bataḳlarda ḳamıs ney-zen olaydım }\end{array}$ & $\begin{array}{l}\text { Dūşizelik el virse Hevāyî dil-i zāra } \\
\text { Ḳașdıyla yeni evlenecek ergen olaydım }\end{array}$ \\
\hline Hevāyī & $\begin{array}{l}\text { Yāri açdum açıl ey manțı dehānım diyerek } \\
\text { Bezme geldi gele ey yahni ḳapanım diyerek }\end{array}$ & $\begin{array}{l}\text { Geveze itdi ġazelerde Hevāyị bizi yār } \\
\text { Söyleye söyleye ey yañşaḳ ozanım diyerek }\end{array}$ \\
\hline Bahāyī & $\begin{array}{l}\text { Nice bir ḥasret günün ile geçer devrānım } \\
\text { Nice bir cıllḳ ḥayālüñ komaya dermānım }\end{array}$ & Ġarażuñ cevr ü cefā ise y \\
\hline $\begin{array}{l}\text { Fāż̀l } \\
\text { Mehmed } \\
\text { Efendi }\end{array}$ & $\begin{array}{l}\text { Böyledir hükm-i ezel mevhibe-i kübrāda } \\
\text { Ki ola emrine efkendileri serdāde } \\
\text { Böyle kāâfile-i ser-bāz-1 cünūn cān-rādde } \\
\text { Āteş-i 'aşķa yanup başlayalar feryāde } \\
\text { Dil șad-1 laḩtı kebāb eyledi aşçı-zāde }\end{array}$ & $\begin{array}{l}\text { Terk edebdür söziñi eyle terāzüde nihān } \\
\text { Olmasun güfte-i mirānede bir loḳma kemān } \\
\text { Söz uzatma yeter ey Ḥāmī-i üftāde nālān } \\
\text { Aġzınuñ loḳması Hakḳ’a degil ol şūhu u cihān } \\
\text { Fāżılā ḥaddini bil söz dime bu saġada }\end{array}$ \\
\hline $\begin{array}{l}\text { İbrāhīm } \\
\text { Fennī }\end{array}$ & 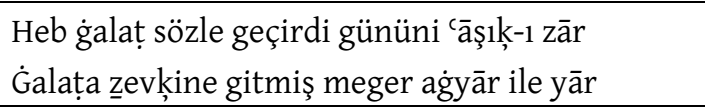 & $\begin{array}{l}\text { Ġālibā Fenni tamām eyleyecekdür żevḳi } \\
\text { Ațalar seyrine düşmüş o perīnüñ şevḳi }\end{array}$ \\
\hline $\begin{array}{l}\text { Osmanzāde } \\
\text { Tā'ib Efendi }\end{array}$ & $\begin{array}{l}\text { Sekbān-1 sefer dīde-i pejmürde-kıyāfet } \\
\text { Kādīlerin ardındaki oğlanına beñzer }\end{array}$ & $\begin{array}{l}\text { Hem-şehrilerüñ tā o ḳadar kessreti var kim } \\
\text { Nābì'nüñ evi şimdi kațır hānına beñzer }\end{array}$ \\
\hline Kānī & $\begin{array}{l}\text { Nümāyandır bilüñ māhiyyeti çāk-ı girīibāndır } \\
\text { Velī entārinüñ rengi görünmez eski kaftāndan }\end{array}$ & $\begin{array}{l}\text { Kesilmiş baş dökülmüş ḳan görünmez ortada } \\
\text { dādı } \\
\text { Velī meydān görünmez ol muṣayḳal țaşl } \\
\text { kalḳandan }\end{array}$ \\
\hline Bahāyī & $\begin{array}{l}\text { Ey Fedāyî görmedüm hiç burnuña beñzer burun } \\
\text { Șanki olmuş șūretüñ üstüne kīr-ḩār-1 burun }\end{array}$ & $\begin{array}{l}\text { Ne ağızı burnı beñzer burnuña ne boz burun } \\
\text { Ger șorarsan yok degil burnuñ yanında yer } \\
\text { burun }\end{array}$ \\
\hline Hevāyī & $\begin{array}{l}\text { Ag̀layup dedi beşikde bebegim } \\
\text { Şişeden idi ḳırıldı sübegim }\end{array}$ & $\begin{array}{l}\text { Dir Hevāyī daḩı söyler idim } \\
\text { Şi'rime baḳsa begenseydi begim }\end{array}$ \\
\hline 'Abdî Efendi & $\begin{array}{l}\text { Ey ki Ḥayrü'd-dīn ile meşhūr olan şerre ala nām } \\
\text { Ḥayf ki şimdi nașılsa vālì-i Yozġad'suñ }\end{array}$ & $\begin{array}{l}\text { Kang̀i ḳabahātiñi ta'dād ḳılsun bu ḳalem } \\
\text { Zümre-i nādān içre cümleden berbādsuñ }\end{array}$ \\
\hline $\begin{array}{l}\text { Koniçeli } \\
\text { Kāzım } \\
\end{array}$ & $\begin{array}{l}\text { Pādişahım naẓar it hāline 'askerlerin } \\
\text { Śevbi șad-pāre ile sekmede keklik gibidir }\end{array}$ & $\begin{array}{l}\text { Ne ița'atle tekāsül ne macaş ü tacin } \\
\text { Ser-te-ser cümlesi efrādı metāik gibidir }\end{array}$ \\
\hline Fatīn Efendi & $\begin{array}{l}\text { Neyledi nişledi gördügi bu çarh-1 ġayūr } \\
\text { İtdi bir şahșṣ-1 denī țab`a ațā-yı medfūr }\end{array}$ & $\begin{array}{l}\text { Bir dahı böyle hațā eyler ise bì-ārām } \\
\text { Eylerim țarz-ı digerde dahı hicdeḳıyām }\end{array}$ \\
\hline
\end{tabular}




\begin{tabular}{|c|c|c|}
\hline Żiyā Paşa & $\begin{array}{l}\text { Bāreka'llāh zihī 'āṭıfet-i Rab Ġafūr } \\
\text { Eyledi cāleme luṭ̂ u kerem-i nā-maḥṣūr }\end{array}$ & $\begin{array}{l}\text { Mazhhar-1 ḳahr Hudāa ola șabāhn[u] ahşāam } \\
\text { Olmaya țabc-1 saḳimimden elem bir dem dedir }\end{array}$ \\
\hline Fatīn Efendi & $\begin{array}{l}\text { Müstekardır țabc-1 erbāb-ı șafāda ibn.lik } \\
\text { Ehline eyler teveccüh bì-irāde ibn.lik }\end{array}$ & $\begin{array}{l}\text { Var ise 'aḳluñ Hevāyī ḳ̂l ebānetde şebāt } \\
\text { Başḳa bir şeydir kabūl itmez afāde ibn.lik }\end{array}$ \\
\hline $\begin{array}{l}\text { Mehmed } \\
\text { Fażll Efendi }\end{array}$ & $\begin{array}{l}\text { Mahtabı bozulup yanmadı kandil-i fesad } \\
\text { Virmeğe hazır iken şulesini fitne Żiyā }\end{array}$ & $\begin{array}{l}\text { Kaldı zulmette hıras-ü havf oldu tārı } \\
\text { Paris'i dārül-emān eyledi cān attı ana }\end{array}$ \\
\hline $\begin{array}{l}\text { Mehmed } \\
\text { Fāżll Efendi }\end{array}$ & $\begin{array}{l}\text { Yok tevārih-i selefte buna benzer diyelim. } \\
\text { Kim Żiyā bey bu sefer etti necāset icrā }\end{array}$ & $\begin{array}{l}\text { Eyledi terk-i vatan Avrupa'ya etti firār } \\
\text { Ana çingāne değil her ne denir ise sezāa }\end{array}$ \\
\hline $\begin{array}{l}\text { Mehmed } \\
\text { Fāż̀l Efendi }\end{array}$ & $\begin{array}{l}\text { Ehl-i īmān eylemez tebiyet-i efrenc bed } \\
\text { Müslümān olsa Żiyā eyler mi idi irtikāb }\end{array}$ & $\begin{array}{l}\text { Bir şakāvet etti ki emsali sebkat etmedi } \\
\text { Varsın olsun İsevīler mezhebiyle kām-yāb }\end{array}$ \\
\hline $\begin{array}{l}\text { Mehmed } \\
\text { Fāżll Efendi }\end{array}$ & $\begin{array}{l}\text { Aksaray kahvelerinde ederdi pazarı } \\
\text { Gecelik bir zer-i mahbubu alırken ücret }\end{array}$ & $\begin{array}{l}\text { Eski halin düşünüp utanacak yok yüzü } \\
\text { Öyle nā-pāk deni etti fesada cürcet }\end{array}$ \\
\hline Żiyā Paşa & $\begin{array}{l}\text { Nev'i insana șalar idi ḳuduz kelb gibi } \\
\text { 'Av 'av hicvin idüb peşīz sādd ib.e nihād }\end{array}$ & $\begin{array}{l}\text { Cevb desti-i hecā ile döküp dişlerini } \\
\text { Aña miḳdārını bildirdi Żiyā-yı iscād }\end{array}$ \\
\hline Nażmī & \begin{tabular}{|l|} 
Şimdiki nażırı maliyye olan menhusuñ \\
Mevlidi Rus olucak kendisi ` Osmanlı mıdır
\end{tabular} & $\begin{array}{l}\text { Hey'eti Ermeniye, Mosḳova beñzer hulḳı } \\
\text { Deme kim aṣlına Şirvanlı mıdır Vanlı mıdır }\end{array}$ \\
\hline $\begin{array}{l}\text { Nüzhet } \\
\text { Efendi }\end{array}$ & $\begin{array}{l}\text { Nāżım sözünde haḳlıdır } \\
\text { Tarihi pek revnaḳlıdır }\end{array}$ & $\begin{array}{l}\text { Nokșanı var bir 'aḳlıdır } \\
\text { Divana geldi ẓır deli }\end{array}$ \\
\hline Mahlassız & $\begin{array}{l}\text { Bunca luṭf u nicam-1 pādişaha mażhar iken } \\
\text { Mülteci oldu kim Efrence Żiyā-i bed-kar }\end{array}$ & $\begin{array}{l}\text { İmr'ül Ḳays'a bedel 'așrda bir şācir idi } \\
\text { Bu sefer Avrupaya itdi firar ol bị̂ar }\end{array}$ \\
\hline Suhte Nấ'ilī & $\begin{array}{l}\text { Bir ebānet-nāme tanzịim eylemiş miskīn Fațīn } \\
\text { Ḩalḳa mā’būn oldığun i'lān itmiş āferīn } \\
\end{array}$ & $\begin{array}{l}\text { Ol dahi bu yüzden itdi dehrde ibkāa-yı nām } \\
\text { Yād olunsun ḩaşre dek mānend-i şeyțān-1 lacīn }\end{array}$ \\
\hline Fatīn Efendi & $\begin{array}{l}\text { Ṣaymayup nān u nemek hakḳıına edebsiz Nā'ilī } \\
\text { Ṣāhibin ḳıbți Ḥüsām'ı zemm edermiş rū-be-rū }\end{array}$ & $\begin{array}{l}\text { Böyle nānkūr olduğın derk itmiş ecdādı kimi } \\
\text { Ḳuleliye gönderidi eski āyudur deyü }\end{array}$ \\
\hline Fatīn Efendi & $\begin{array}{l}\text { Nā'ilīi-i sūhte Hakk-1 nemek bilmez [.] nedir } \\
\text { Söylemiş Ḳıți Hüsām'uñ ismine hicviyeler }\end{array}$ & $\begin{array}{l}\text { Vāḳıf olsa ḳıbtiyan mülkünden ifrāz eyleyip } \\
\text { Azğun ayıdır deyü Eyvanserāy vaḳf eder }\end{array}$ \\
\hline Fatīn Efendi & $\begin{array}{l}\text { Nā'ilì-i zenn bahrr isterse itsün güft [ü] gū } \\
\text { Kim a. ağılzlı kahpenünn güftārını. }\end{array}$ & $\begin{array}{l}\text { Gönder didi ḳız ḳarındaşı o.....yı baña } \\
\text { Bildirürdüm s... s... ḳahpenüñ miḳdārını. }\end{array}$ \\
\hline Fatīn Efendi & $\begin{array}{l}\text { Ak büyük hammāmınuñ hayli aǵrıtmışdı(?) } \\
\text { yüzin } \\
\text { Nā'ilīi ḳaḥpe ande köhne bir dikeñ iken. }\end{array}$ & $\begin{array}{l}\text { Maǵlumān bilmem naș̣l s....o murdār ibneye } \\
\text { Dā’’imā ağzı gibi gö*ti dahıı nā-pāk iken. }\end{array}$ \\
\hline Fatīn Efendi & $\begin{array}{l}\text { Nankūrlük eyleyüp șaf kibārı fașl ider } \\
\text { Nā'ilīi-i suhte Ḥaḳ nemek bilmez nedir. }\end{array}$ & $\begin{array}{l}\text { Āteş-i hicv ile halkụuñ cānını baḳmaḳtadır } \\
\text { Öyle bir Nemrūd kim sivrisinek bilmez nedir. }\end{array}$ \\
\hline Fatîn Efendi & $\begin{array}{l}\text { Nā'ilī'ye ........ }{ }^{2} \text { hürrmet eylerse deger } \\
\text { Dīnsiz bir feylesof küfr-i istināsıdır. }\end{array}$ & $\begin{array}{l}\text { Rūm pațriki olur kāfir kendi ḩasb'ül-ferur } \\
\text { Babası şehr-i Manastırda büyük papasdır. }\end{array}$ \\
\hline 'AzmīBey & $\begin{array}{l}\text { Yogiken kudreti nik ü bedi tefrika Fatīn } \\
\text { Şu'arā halkına bir tezkịre tenmik etmiş }\end{array}$ & $\begin{array}{l}\text { Cühela zümresini medh ü sena etti deyü } \\
\text { Bazı memduhu verip hak onu tasdik etmiş }\end{array}$ \\
\hline Hevāyī & $\begin{array}{l}\text { Niyāẓ̄i-i gedā kim cümlenüñ manẓūrı olmışdur } \\
\text { Tehī destān-1 cașruñ server u mağrūrı olmuştur. }\end{array}$ & $\begin{array}{l}\text { Hevāyī gerçi bir vapur idi ammā bugünlerde } \\
\text { Düşüp șaḥn-1 kelāma 'ayn-1 söz vapuru olmuştur. }\end{array}$ \\
\hline
\end{tabular}

\footnotetext{
${ }^{2}$ Mecmuada bu kısım okunamamıştır.
} 


\begin{tabular}{|c|c|c|}
\hline Hevāyī & $\begin{array}{l}\text { Deli Kāậ̣ vefāt itmiş idi Çıldır ḳażāsında } \\
\text { Yarı bir aḳla tevcīh olunmuşdi bu āşināda. }\end{array}$ & $\begin{array}{l}\text { Koca ḳaḍ̂-1 İslāmbol olursa ol ḳara cāhil } \\
\text { Anuñ ceddi ḳoca bāț̣l idi ṣadr-1 mu'allāda }\end{array}$ \\
\hline Fāżıl Paşa & $\begin{array}{l}\text { Bāreka'llāh zihī kevkebe-i ‘ālü'l-‘āl } \\
\text { Levhāşallāh ‘aceb nușret-i feyż ü ikkbāl }\end{array}$ & $\begin{array}{l}\text { Luṭf u i ihsānı gibi ömri ola nā-ma'dūd } \\
\text { Dîn ü īmānı kadar kesb ide feyż ü iḳbāl }\end{array}$ \\
\hline Fatīn Efendi & $\begin{array}{l}\text { Sāye-i nahşş şöhret olmuşken hümā[y]-1 Aksāray } \\
\text { Būm-1 şūma oldı mesken gūcihā-yı Akssāray }\end{array}$ & $\begin{array}{l}\text { Eylesün andan zen ü mahbūbı rıžkla mūrdār } \\
\text { Ey Fațīin görsün gözüñ̃ dā'im șafā-yı Akssāray }\end{array}$ \\
\hline 'Abdī Bey & $\begin{array}{l}\text { Düşümān-ı kavīnüñ inficāli artar eksilmez } \\
\text { Firansızla Purusya'nuñ cidāli artar eksilmez }\end{array}$ & $\begin{array}{l}\text { Mücīz olan egerçi merd-i dānā 'Abdiyā ammā } \\
\text { Zamanın ārzū-yı yāl u bālı artar eksilmez }\end{array}$ \\
\hline ‘Ali & $\begin{array}{l}\text { Cihānuñ hāal-i nā-hem-vārr elbet artar eksilmez } \\
\text { Reh-i nā-refte-i fisk u rezālet artar eksilmez }\end{array}$ & $\begin{array}{l}\text { Cenāb-i Hakk mu'īni olsun ehl-i dīn ü īmānuñ } \\
\text { Bu `ālī ümmete cevr ü ihānet artar eksilmez }\end{array}$ \\
\hline
\end{tabular}

Tabloda görüldüğü üzere mecmuada yer alan şiirlerin çoğu hiciv manzumeleridir. Şairler birbirlerini ağır ithamlarla suçlayıp (dinsizlik, hainlik vb.) birbirlerinin fiziksel özellikleri(Kekez, batlıcan burun, kanbur vb.) ile de dalga geçmişlerdir. Elbette mecmuadaki manzumelerin hepsi şairlerin birbirlerine yazdığı hicivleri kapsamamaktadır. XIX. Yüzyılda meydana gelen önemli siyasi ve sosyal olaylar hakkında da bilgiler yer almaktadır:

Fıransız ile Prusya harbi dehşet virdi dünyāya

Bozuldu Avrupa āsāyişi ḳan-ı silveş aḳdı

Fransa ile Prusya(Almanya) harbinden bahsederek Avrupa'da güvenliğin kalmadığına ve birçok kan aktığına dair bilgiler verilmiştir.

Alaman 'askeri her yerde oldu hașmina gālib

Purusya ḳralının iḳbāle reșk eylesün celb

Almanya’nın XIX. Yüzyılda bilindiği üzere birçok ülkeye karşı galibiyeti dünyada korkuya neden olmuş ve ilerleyişleri durdurulmak istenmiştir.

\author{
Lisān-1 Fransīviye olmaz ise bir kişi vākıf \\ Çekerdi zilleti 'așīce sayar idi anı devlet \\ Yapılmış idi emr-i Napolyun ile bir mekteb \\ Anı īcād itmişdi yeni bir kāfir nekbet
}

1840'da İstanbul'da ilk Fransız okulu açılır. Şair burada 19. Yüzyılda Osmanlı'nın Fransa'nın emriyle açtığı okullardan bahsetmiştir ve bu durumdan rahatsız olduğunu dile getirmiştir.

Yitirdü tāc vü tahtı oldu Almanya esīiri kim

Cihāngìr olmuş iken rūbc-1 meskūn üzre Napolyon

III. Napolyon'un 83.000 kişilik ordusu ile Sedan'da Prusyalılara esir düşmesi(Armaoğlu:1997:325) olayına istinaden yazılmı̧ bir beyittir. 
Verilen beyit/kıtaların yazarı hakkında bir bilgi bulunmamaktadır. Örneklerde de görüldüğü gibi mecmuada dönemin siyasi olayları hakkında da bilgiler yer almaktadır. XIX. Yüzyılda Fransa'nın Almanya'ya yenilmesi, Napolyon'un Almanlara esir düşmesi(1870) ve Avrupa'da bozulan asayişin de üzerinde durulması oldukça dikkat çekici ve önemlidir. Çalışma, hicivler üzerinde yoğunlaştığı için bu konuda ayrıntıya girilmemiştir.

\section{Sonuç}

Bu çalışmada Millet Kütüphanesi'nde AE Manzum 558 numarada kayitlı olan Hicivler Mecmuásı adlı eserin adı, te'lif tarihi, yazarı, içeriği, şekil özellikleri ve şiirlerden örnekler incelenmiştir. Şiirlerin tamamına yakınında küfür ve müstehcen ifadeler ön planda yer almı̧tır. Bu ifadelerin müsebbipleri çoğunlukla; sahte dindarlık, kişisel husumetler, dine uygun olmayan davranışlar ve devlet adamlarının başarısızlıkları gerekçe gösterilerek saldırı oklarına maruz kalmışlardır. Çoğu şiirlerde mahlas veya doğrudan isim bildirilerek hicivlere yer verildiyse de bazı eserlerde kişiler isim veya mahlas bildirilmeden hicvedilmiştir. Eserde tespit edilen bilgiler, şairler, şiirleri ayrıca tablolarla desteklenerek verilmiş ve böylece en doğru bilgiler elde edilmeye çalışılmıştır.

Daha önce tez veya makale konusu olarak dahi çalışılmamış adına sadece birkaç araştırmacının yer verdiği Hicivler Mecmuası adlı eser incelenmiştir. Bu mecmuada, Türk edebiyatının önemli şairlerinin daha doğrusu heccavlarının, hiciv şiirlerine yer verilmiştir. Eser özellikle ağır, hakaret adına, sert söylem içeren hicivler içermekte olup Türk edebiyatı ve edebiyat tarihi araştırmacıları için oldukça zengin bir malzeme kaynağıdır. Ayrıca ünlü şairlerden de bu konuda şiirler içermesi ve pek az bilinen bazı şairlerin birbirlerine hiciv yazacak kadar kavgalı olmaları dikkat çeken unsurlardan biridir. Eserde yer alan çoğu hicvin yazılış sebebi göz önünde bulundurulursa dönemin siyasi ve sosyal hayatı hakkında da fikir sahibi olunabileceği görülmüştür.

\section{Kaynakça}

Ahmet Vefik Paşa. (2000). Lehçe-i Osmânî (haz: R. Toparlı). Ankara: TDK Yay.

Aktunç, Hulki. (1998). Türkçenin Büyük Argo Sözlüğü.(Birinci Baskı). İstanbul: Yapı Kredi Yayınlar1.

Armaoğlu Fahir.(1997). 19. Yüzyıl Siyasi Tarihi (1789-1914). TTK Yayınları.

Aydemir, Yaşar (2007). Metin Neşrinde Mecmuaların Rolü ve Karşılaşılan Problemler. Turkish Studies/Türkoloji Araştırmaları. S.2/3, s. 123-126.

Bingölçe, Filiz. (2011). (Tanıklarıyla) Osmanlı Argosu Sözlüğü. (Birinci Baskı). Ankara: Sage Yayıncilik.

Develioğlu, Ferit. (2010). Osmanlı-Türkçe Ansiklopedik Lûgat.(Haz. Güneyçal, A. S.). (Yirmi altıncı Bask1). Ankara: Aydın Kitabevi Yayınları.

Develioğlu, Ferit. (1980). Türk Argosu İnceleme ve Sözlük. (Altıncı Baskı). Ankara: Aydın Kitabevi.

Durmuş, İsmail. (1998). "Hiciv”. Diyanet İslâm Ansiklopedisi. C. 17. Ankara: TDV Yayınları.

Yayıncilik.

Kanar, Mehmet. (2011). Farş̧a Türkçe Sözlük, (Üçüncü Baskı.). İstanbul: Say Yayınları.

Kanar, Mehmet. Osmanlı Türkçesi Sözlüğü. İstanbul: Say Yayınları 
Kocaer, Abdullah Feyzi.(Tarihsiz.).Imam Nevevî. Riyâzü's Sâlihîn. Sabah Gazetesi Yayınları.

Köksal, Mehmet Fatih. (2012). "Siir Mecmûalarının Önemi ve Mecmûaların Sistematik Tasnifi Projesi (MESTAP)”. Eski Türk Edebiyatı Çalışmaları VII Mecmûa: Osmanlı Edebiyatının Kırkambarı. İstanbul: Turkuaz Yayınları.

Kut, Günay. (1986). Mecmua”. Türk Dili ve Edebiyatı Ansiklopedisi. C. VI. İstanbul: Dergâh Yay. 170-176.

Levend, Agah Sırrı. (1984). Türk Edebiyatı Tarihi I. (İkinci Baskı). Ankara: T.T.K Yayınları.

Mermer, Ahmet. Alıcı, Lütfi, Eflatun. Muvaffak, Bayram,Yavuz. Koç Keskin, Neslihan. (2014).

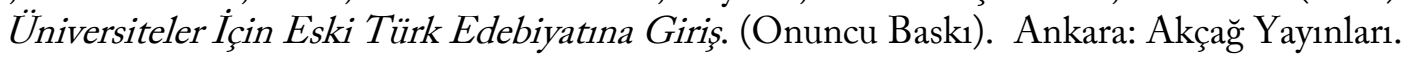

Mutçalı, Serdar. (2004). Türkçe-Arapça Sözlük. İstanbul: Dağarcık Yayınları.

Mütercim Âsım Efendi (2009). Burhân-ı Katı. (İkinci Baskı). Ankara: TDK Yayınları.

Parlatır, İsmail. (2006). Osmanlı Türkçesi Sözlüğ̈̈. (Birinci Baskı). Ankara: Yargı Yayınevi.

Fakültesi Dergisi (34): 313-352.

Pakalın, Mehmet Zeki. (1983). Osmanlı Tarih Deyimleri ve Terimleri Sözlüğ̈̈ I-II-III. İstanbul: Milli Eğitim Basımevi.

Parlatır, İsmail. (2010). Osmanlı Türkçesi Sözlüğü, Ankara: Yarg1 Yayınevi

Redhouse, Sir James William. (1987). A Turkishand English Lexicon Shewing in English The Significations of The Turkish Terms. İstanbul: Printed for the American mission by A. H.Boyajian.

Şemseddin Sami. (2007). Kâmûs-1 Türkî. İstanbul: Çağrı Yayınları.

Tunç, Semra.-Sevgi, Ahmet. (2015). "Livâyî Bey Mecmû‘ası”. Selçuk Üniversitesi Edebiyat Fakültesi Dergisi.

Ünver, İsmail. (2008). Çeviri yazıda Yazım Birliği Üzerine Öneriler. Turkish Studies. 